\title{
A computational multi-targeting approach for drug repositioning for psoriasis treatment
}

\author{
Akachukwu Ibezim", Emmanuel Onah¹, Ebubechukwu N. Dim² and Fidele Ntie-Kang ${ }^{3,4^{*}}$
}

\begin{abstract}
Background: Psoriasis is an autoimmune inflammatory skin disease that affects $0.5-3 \%$ of the world's population and current treatment options are posed with limitations. The reduced risk of failure in clinical trials for repositioned drug candidates and the time and cost-effectiveness has popularized drug reposition and computational methods in the drug research community.

Results: The current study attempts to reposition approved drugs for the treatment of psoriasis by docking about 2000 approved drug molecules against fifteen selected and validated anti-psoriatic targets. The docking results showed that a good number of the dataset interacted favorably with the targets as most of them had - 11.00 to $-10.00 \mathrm{kcal} / \mathrm{mol}$ binding free energies across the targets. The percentage of the dataset with binding affinity higher than the co-crystallized ligands ranged from $34.76 \%$ (JAK-3) to $0.73 \%$ (Rac-1). It was observed that 12 out of the $0.73 \%$ outperformed all the co-crystallized ligands across the 15 studied proteins. All the 12 drugs identified are currently indicated as either antiviral or anticancer drugs and are of purine and pyrimidine nuclei. This is not surprising given that there is similarity in the mechanism of the mentioned diseases.
\end{abstract}

Conclusion: This study, therefore, suggests that; antiviral and anticancer drugs could have anti-psoriatic effects, and molecules with purine and pyrimidine structural architecture are likely templates to consider in developing antipsoriatic agents.

Keywords: Binding free energies, Docking, Drug repositioning, Psoriasis

\section{Background}

Psoriasis is an autoimmune inflammatory skin disease that affects $0.5-3 \%$ of the world's population [1]. It is caused by the complex interplay of the innate and adaptive immune systems together with a wide array of genetic and environmental factors. Environmental triggers such as stress, injury, drugs, and the disease start the self-propelled cycle of inflammation culminating in

\footnotetext{
* Correspondence: akachukwu.ibezim@unn.edu.ng; ntiekfidele@gmail.com; fidele.ntie-kang@ubuea.cm

'Department of Pharmaceutical and Medicinal Chemistry, University of Nigeria, Nsukka, Nigeria

${ }^{3}$ Department of Chemistry, University of Buea, Buea, Cameroon

Full list of author information is available at the end of the article
}

hyper-proliferation due to the activation of the innate immune system cells [2-5]. The disease is associated with decreased quality of life and multiple comorbid conditions, including metabolic syndrome, cardiovascular diseases, obesity, diabetes type 2 and Crohn's disease [6-8]. In spite of effort by many researchers, there is currently no drug for curing the disease only for management purposes. Therefore, chemotherapy for this disease is highly needed $[9,10]$.

The goal of drug repurposing is to discover new uses of old (known) drugs [11]. The field of drug repositioning is growing rapidly because it starts from compounds, which are often Food and Drug Administration (FDA) approved drugs, with well-characterized

(c) The Author(s). 2021 Open Access This article is licensed under a Creative Commons Attribution 4.0 International License, which permits use, sharing, adaptation, distribution and reproduction in any medium or format, as long as you give appropriate credit to the original author(s) and the source, provide a link to the Creative Commons licence, and indicate if changes were made. The images or other third party material in this article are included in the article's Creative Commons licence, unless indicated otherwise in a credit line to the material. If material is not included in the article's Creative Commons licence and your intended use is not permitted by statutory regulation or exceeds the permitted use, you will need to obtain permission directly from the copyright holder. To view a copy of this licence, visit http://creativecommons.org/licenses/by/4.0/ The Creative Commons Public Domain Dedication waiver (http://creativecommons.org/publicdomain/zero/1.0/) applies to the data made available in this article, unless otherwise stated in a credit line to the data. 
pharmacology and safety profiles. Benefits accompanying this strategy are reduction in the risk of attrition in drug development during clinical trials and subsequently cost $[12,13]$. Moreover, the successes recorded through this strategy have popularized its use in drug discovery courses. For example, Pfizer's sildenafil is now also prescribed for erectile dysfunction, Celgene's thalidomide is repurposed for cancer, Upjohn's minoxidil for alopecia and so on $[14,15]$. When compared with diseases like cancer where previously known drugs have been repurposed, e.g. the painkiller aspirin for cancer prevention, metformin previously known for the treatment of type- 2 diabetes to protect against cancer development $[16,17]$, no repurposed drug has been established as a treatment for psoriasis to date, thus suggesting the current study.

The use of computers and computer software in drug research has become a common practice because it saves cost and time. In addition, due to advances in technology and computer power, accuracy of theoretical results is improving significantly and as such their predictions represent experimental results more and more [18-23]. In our previous investigation of the medicinal plant, Psorospermum febrifugum Spach, we provided evidence that confirm its ethnopharmacological usage as antipsoriatic agent and further identified forty-two fatty acids from the GC-MS chromatogram of the most active extract fraction which could be responsible for its biological activity [24].

In this study, efforts have been made to screen about 2000 currently approved drugs against fifteen selected and validated anti-psoriatic drug targets through molecular docking with the aim of repurposing strong binders for the treatment of the disease. Analysis to identify drugs with better docking scores than co-crystallized ligands across the entire protein targets was made and their common motif noted. The binding modes of the most interesting candidate in the proteins' cavities were finally examined.

\section{Materials and methods}

Preparation of the approved drugs for molecular docking The coordinate files, numbering 1852, of the approved drugs were retrieved from the ZINC database [25] and prepared by the Molecular Operating Environment software (MOE) [26]. The MOE 3-dimensional (3-D) protonation tool and MMFF94 force field [27] were, respectively, used to protonate the structures of the dataset and generate low energy structures to a gradient of $0.001 \mathrm{kcal} / \mathrm{mol}$ at $300 \mathrm{~K}$ and $\mathrm{pH}$ of 7.0.

\section{Preparation of the target proteins for modeling purpose}

Fifteen selected X-ray crystal structures of enzymes implicated in the disease mechanism alongside their cocrystallized ligands were retrieved from the protein data bank [28]. Water and other non-essential small molecules co-crystallized with the protein-ligand complexes were deleted and then polar hydrogen atoms were added after which their low energies were generated using the ffG53a6 in Gromacs 4.5.5 [29]. Finally, each protein and their cocrystallized ligand was separated and saved as separate files.

\section{Docking procedure}

The cavities occupied by each co-crystallized ligand were considered as the binding site of the fifteen antipsoriatic targets and three main stages implemented in MOE DockTool were employed in docking the dataset into them as follows: First the program performed a systematic search to generate all combinations of angles for each ligand from its single 3-D conformation. Next Triangle Matcher tool placed a collection of poses, generated from the pool of ligand conformations, into the protein target binding site. Finally, London dG scoring function computed the binding free energy of the ligand from a given pose by taking cognizance of plethora of factors such as the average rotational and translational entropy terms, energy lost as a result of the flexibility of the ligand, hydrogen bonding, metal contacts and a desolvation term due the volumes of the atoms of the protein and ligand in contact with solvent. The program was set to retain the top 5 poses for each ligand. Note that the docking parameters were validated by using only the 3-D affinity grids which reproduced the experimental poses of the co-crystallized ligands within root mean square deviation (rmsd) of $<2.0 \AA$.

\section{Results and discussion}

Since psoriasis is a chronic disease with no known cure, available drugs are only used to manage the symptoms and improve patients' quality of life [30]. Thus, drugs for the management of psoriasis should be safe for long term use. They should also be cost-effective and very convenient to administer. However, the current drugs for the management of psoriasis have limitations ranging from lack of potency (topical agents), high toxicity (anticancer agents), high cost and relatively large molecular size. Furthermore, biologics require engineering from live, specialized cells [31, 32]. Due to these limitations, these drugs are not readily accessible to patients and those that can afford them still have problems with compliance because of the high untoward effects. This situation provided the impetus to search for better, cost-effective and safer anti-psoriatic drugs.

\section{Virtual screening of the approved drugs on the selected Antipsoriatic targets}

Several parameters for the centroids and dimensions of grids were centered on each of the proteins' binding sites and only the ones that reproduced the experimental ligands poses were retained as shown in Table 1 and used in the virtual screening procedure. The rmsd values from the docking validation results ranged from 0.86 to 
Table 1 Validation of the docking protocol employed in the study

\begin{tabular}{|c|c|c|c|c|c|c|c|c|}
\hline \multirow[t]{2}{*}{ Target } & \multirow{2}{*}{$\begin{array}{l}\text { PDB } \\
\text { Code }\end{array}$} & \multicolumn{3}{|c|}{ Grid Box Origin } & \multicolumn{3}{|c|}{ Grid Box Radius } & \multirow[t]{2}{*}{ RMSD } \\
\hline & & $x$ & $Y$ & $\mathrm{Z}$ & $x$ & $\mathrm{Y}$ & $\mathrm{Z}$ & \\
\hline $\mathrm{A}_{2} \mathrm{AR}$ & $2 Y \mathrm{YDO}$ & -28.9352 & 9.0723 & -23.3486 & 4.0 & 7.0 & 4.0 & 1.60 \\
\hline BTK & 4OTF & -37.9926 & 26.1210 & -9.4603 & 7.0 & 6.0 & 10.5 & 1.56 \\
\hline CS & $5 \mathrm{QC} 5$ & 42.8295 & -4.4045 & 42.1155 & 8.0 & 8.0 & 8.0 & 1.65 \\
\hline$\|-17 a$ & $5 \mathrm{HI} 4$ & 78.6552 & -44.1998 & -45.5098 & 8.0 & 8.0 & 8.0 & 1.88 \\
\hline $11-23$ & 3QWR & 23.5974 & -26.6082 & -51.9151 & 8.0 & 8.0 & 8.0 & 1.72 \\
\hline JaK-3 & $5 T T S$ & -0.2570 & 17.8777 & -5.2946 & 7.7 & 8.0 & 7.0 & 1.53 \\
\hline P38-MAPK & 3NEW & 24.4628 & 16.3186 & 10.6828 & 5.0 & 5.5 & 4.9 & 0.94 \\
\hline PDE-4 & $5 K 11$ & 12.5596 & 3.8457 & 68.4582 & 6.0 & 6.0 & 6.3 & 1.48 \\
\hline PAD & $4 X 8 G$ & 26.8987 & 45.0298 & 26.6235 & 8.0 & 8.0 & 8.0 & 1.64 \\
\hline Pim-1 Kinase & $4 A 7 C$ & -41.1394 & -3.0677 & 2.5015 & 6.0 & 5.5 & 6.2 & 0.86 \\
\hline PKC & $5 \mathrm{F9E}$ & 26.2347 & 78.7212 & 29.1280 & 8.0 & 6.0 & 8.0 & 1.16 \\
\hline RAC-1 & $5 \mathrm{VCU}$ & 2.3215 & -21.9062 & -6.8930 & 8.0 & 5.0 & 8.0 & 1.23 \\
\hline SPK & $4 X \mathrm{XG} 6$ & 0.4376 & -3.1674 & 7.0491 & 6.0 & 7.0 & 6.0 & 1.86 \\
\hline S1PR & $3 \mathrm{~V} 2 \mathrm{~W}$ & 7.4851 & 17.6949 & -8.9697 & 8.0 & 8.0 & 8.0 & 1.66 \\
\hline TNF-a & $2 A Z 5$ & -19.0000 & 74.2776 & 33.5624 & 6.0 & 6.3 & 6.8 & 1.47 \\
\hline
\end{tabular}

$A_{2} A R$ Adenosine A2 Receptor, BTK Bruton's Tyrosine Kinase, CS Cathepsin S, IL-17A Interleukin-17A, IL-23 Interleukin-23, JaK-3 Janus Kinase 3, P38-MAPK Mitogenactivated Protein Kinase-p38, PDE-4 Phosphodiesterase-4, PAD Peptidylarginine Deiminase, Pim-1 kinase Provirallntegration site for Moloney Murine Leukemia Virus-1 Kinase, PKC Protein Kinase C, RAC-1 Ras-related C3 Botulinum Toxin Substrate-1, S1PR Sphingosine 1-Phosphate Receptor, SPK Protein Kinase C, and TNF-a Tumor Necrosis Factor-alpha

$1.88 \AA$ with co-crystallized inhibitors of Pim-1 kinase and P38-MAPK showing the best dock poses. Since all the values are within acceptable range, they were then used to carry out the docking calculations.

The distribution of the docking scores of the approved drugs across the studied targets ranged from low negative values $(-22.81 \mathrm{kcal} / \mathrm{mol})$ to positive values (Table 2). The most susceptible protein to the dataset was observed to be the tyrosine kinase (JAK-3) which is confirmed to participate in the inflammatory affliction. About $35 \%$ of the dataset demonstrated higher binding affinity for JAK-3 than its specific co-crystallized

Table 2 Number of the drugs with higher binding affinity than the co-crystallized ligands for each studied protein targets, their corresponding percentages of the dataset and the docking score of the topmost scorer

\begin{tabular}{lllll}
\hline $\begin{array}{l}\text { Protein } \\
\text { Target }\end{array}$ & $\begin{array}{l}\text { Co-crystallized } \\
\text { ligand (kcal/mol) }\end{array}$ & $\begin{array}{l}\text { No. of compounds with higher binding } \\
\text { affinity than co-crystallized ligands }\end{array}$ & $\begin{array}{l}\text { Percentage of dataset with higher binding } \\
\text { affinity than co-crystallized ligands }\end{array}$ & $\begin{array}{l}\text { Maximum } \\
\text { score (kcal/mol) }\end{array}$ \\
\hline A2AR & -12.62 & 79 & 4.27 & -16.84 \\
BTK & -13.26 & 35 & 1.91 & -18.26 \\
CS & -11.65 & 55 & 2.99 & -17.38 \\
IL-17A & -10.59 & 161 & 8.76 & -15.64 \\
IL-23 & -11.91 & 13 & 0.73 & -15.62 \\
JAK-3 & -9.73 & 641 & 34.64 & -16.31 \\
P38-MAPK & -12.32 & 78 & 4.24 & -17.67 \\
PDE-4 & -13.91 & 36 & 2.06 & -16.74 \\
PAD & -13.91 & 24 & 1.33 & -18.23 \\
Pim-1 Kinase & -14.68 & 14 & 0.8 & -19.08 \\
PKC & -12.23 & 97 & 5.24 & -18.92 \\
RAC-1 & -16.08 & 19 & 1.05 & -20.91 \\
SPK & -13.02 & 107 & 1.23 & -16.64 \\
SIPR & -17.36 & 19 & 1.06 & -22.81 \\
TNF- -10 & -10.81 & 46 & 2.5 & -15.52 \\
\hline
\end{tabular}


<smiles>CC(C)OC(=O)[C@H](C)NP(=O)(OCC1[C@H]2O[C@@]1(F)C1C(=O)NC(=O)C=CC12)Oc1ccccc1</smiles>

Sofosbuvir<smiles>COCc1nc(N)nc2c1ncn2[C@@H]1O[C@H]2O[C@@H]1[C@@H](O)C2O</smiles><smiles></smiles><smiles>O=c1[nH]cc(F)c(=O)[nH]1</smiles>

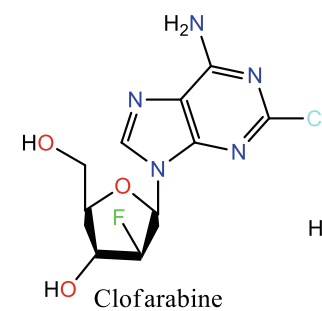<smiles>Nc1nc2c(ncn2COC(O)CO)c(=O)[nH]1</smiles><smiles>Nc1ccn([C@@H]2O[C@H]3COC[C@H]2O3)c(=O)n1</smiles>
Lamivudine<smiles>Nc1nc2c(ncn2CCC(CO)CO)c(=O)[nH]1</smiles>

Ganciclovir<smiles>Nc1nc(O)nc2c1ncn2[C@@H]1C[C@H](O)[C@@H](CO)O1</smiles><smiles>Nc1ccn([C@@H]2C[C@H]3[C@@H](CO)O[C@@H]32)c(=O)n1</smiles><smiles></smiles><smiles>Nc1nc(F)nc2c1ncn2[C@@H]1O[C@@H]2O[C@@H]1[C@@H](COP(=O)(O)O)[C@@H]2O</smiles>

Fig. 1 2-dimensional structures of the twelve drugs that showed higher binding affinity for all the studied 15 protein targets than each of their corresponding co-crystallized ligands

inhibitor. This lends credibility to our docking method because JAK- 3 had been reported to be a promiscuous protein [33]. Next to JAK-3 are IL-17A, PKC, $\mathrm{A}_{2} \mathrm{AR}$ and P38-MAPK respectively with about $9,5,4$ and $4 \%$ of the dataset scoring lower than its co-crystallized ligands. The rest have a low percentage of the dataset in that category. The least interactive protein was IL-23 which has only thirteen drugs scoring better than its co-crystallized ligand. These observations are consistent with earlier reports [34]. We compared the performance of the thirteen compounds across the other 14 targets and realized all of them scored higher than all the co-crystallized ligands except one. In other words, inhibitors of IL-23 will likely exhibit broad spectra of activities against various types of psoriasis. Interestingly, all the twelve drugs are either purine or pyrimidine nucleoside/nucleotide

Table 3 Names, chemical classes and current indications of the 12 drugs

\begin{tabular}{|c|c|c|c|}
\hline Drug Name & Chemical Class/ Structural Scaffold & Current Indications & References \\
\hline Sofosbuvir & Pyrimidine nucleotide analog & Hepatitis C & [35] \\
\hline Nelarabine & Purine nucleoside analog & Acute lymphoblastic Leukemia & [36] \\
\hline Entecavir & Purine nucleoside analog & Hepatitis B & [37] \\
\hline Clofarabine & Purine nucleoside analog & Acute lymphoblastic leukemia & [38] \\
\hline Ganciclovir & Purine nucleoside analog & Cytomegalovirus infection & [39] \\
\hline Fluorouracil & Pyrimidine analog & Various cancers & [40] \\
\hline Penciclovir & Purine analog & Herpes virus infections & [41] \\
\hline Lamivudine & Pyrimidine nucleoside analog & HIV/AIDS, Hepatitis B & [42] \\
\hline Cladribine & Purine nucleoside analog & B-cell chronic lymphocytic leukemia & [43] \\
\hline Zalcitabine & Pyrimidine nucleoside analog & HIV/AIDS & [44] \\
\hline Fludarabine & Purine nucleotide analog & Leukemia and Lymphoma & [45] \\
\hline Cytarabine & Pyrimidine nucleoside analog & Leukemia and Lymphoma & [46] \\
\hline
\end{tabular}




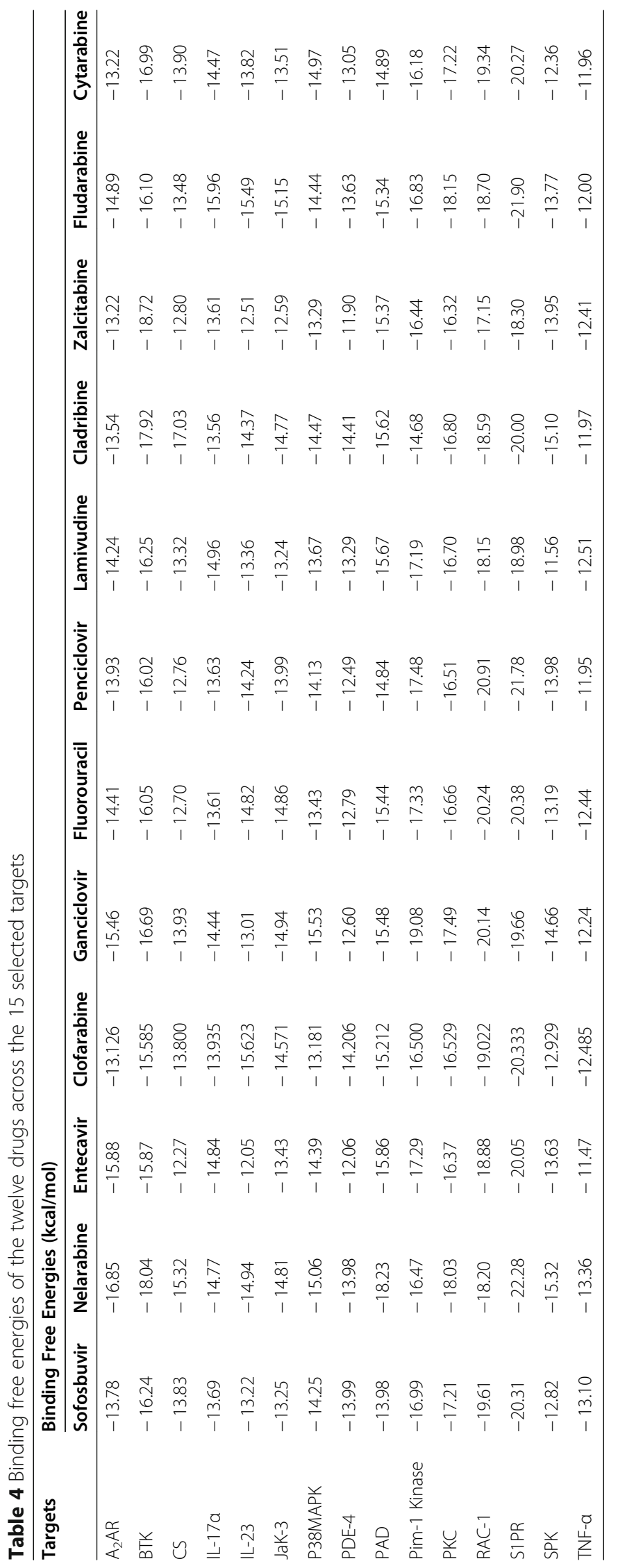


analogues, except for fluorouracil which is a simple pyrimidine (uracil) derivative with neither phosphate group nor modified sugar side chain (Fig. 1).

The interesting binding interactions shown by the 12 compounds toward the selected protein targets could be based on their highly functionalized nature, with many polar moieties and the presence of cyclic aromatic groups whose pi-electrons are readily available to engage into hydrophobic bonding. The polar nature of the drugs is also evident from their molecular structures. Nelarabine, entecavir, clofarabine, ganciclovir, penciclovir, and fludarabine are derivatives of purine base while sofosbuvir, fluorouracil, zalcitabine, and cytarabine are derivatives of pyrimidine base. These polar moieties can easily be involved in $\mathrm{H}$ bonding. Current indications of the 12 drugs presented in Table 3 show that they are either antiviral or anticancer drugs. Thus, purine and pyrimidine based antiviral and anticancer drugs are potential chemotherapeutic options for handling psoriasis. Examination of the individual scores of each of the twelve for the 15 targets (Table 4) revealed nelarabine as the topscorer for five targets $\left(\mathrm{A}_{2} \mathrm{AR}, \mathrm{PAD}, \mathrm{SPK}\right.$, SIP receptor and TNF- $\alpha$ ), followed by fludarabine with highest binding affinity for IL-17, JAK-3 and PKC. Apart from cladribine which topped for CS and PDE4 , the rest of the drugs either emerged as the topscorer for just one target or none. Nelarabine poses in the binding sites of $\mathrm{A}_{2} \mathrm{AR}, \mathrm{PAD}$ and SIP receptors as shown in Fig. 2 confirmed our earlier hypothesis as it was observed to make a series of arene-carbon, arene$\mathrm{H}$ and pi-pi interactions with the various protein binding sites residues.

These 12 known drugs (shown in Table 3 and Fig. 2) identified by the described computational approach could be possible candidates for the treatment of psoriasis. These are essentially antiviral or antineoplastic drugs and have previously been reported to show some side effects. As an example, common side effects of sofosbuvir (administered as tablets with brand name: Sovaldi) include: fatigue, headache, nausea, insomnia, itching, anemia, weakness and rash. This drug is a nucleotide analogue inhibitor of the hepatitis $\mathrm{C}$ virus (HCV) NS5B polymerase used for the treatment of chronic hepatitis $\mathrm{C}(\mathrm{CHC})$ infection. It is often employed as part of a combination antiviral treatment regimen. Fluorouracil has been administered as a topical cream and as an injection. It has appeared in several brand names (including adrucil) approved by the FDA as an injection acting as a nucleoside metabolic inhibitor for the treatment of patients with several cancer types, including adenocarcinoma of the colon and rectum, adenocarcinoma of the breast, gastric adenocarcinoma and pancreatic adenocarcinoma. The drug causes hair loss, nausea, bruising, among other effects (RxList, https://www.rxlist.com/ adrucil-drug.htm\#description). Cytarabine is an injectable cancer medication for the treatment of certain types of blood cancers (leukemia), particularly those associated with meningitis. Common side effects include nausea and vomiting, appetite loss, diarrhea, constipation, headache, dizziness, injection site reactions (e.g. pain, swelling, and redness), drowsiness, weakness, memory problems, back pain, pain in your arms or legs, or trouble sleeping (insomnia). Since psoriasis is a skin disease, the administration route for the repurposing of some of these injectable drugs could avoid the use of injections to reduce the side effects observed by injecting patients, preferably by topical administration. In the case of sofosbuvir, side effects related to the ingestion of the tablets (e.g. fatigue, headache, nausea, etc.) could be avoided when administered topically. This, together with other drugs currently available as non-ingestible and non-injectable powders would be most suitable for repurposing as potential drugs for the treatment of psoriasis.

\section{Conclusion}

In this study, we identified 12 FDA approved drugs (nelarabine, fludarabine, clofarabine, cladribine, zalcitabine, cytarabine, ganciclovir, penciclovir, sofosbuvir, entecavir, fluorouracil, and lamivudine) with higher
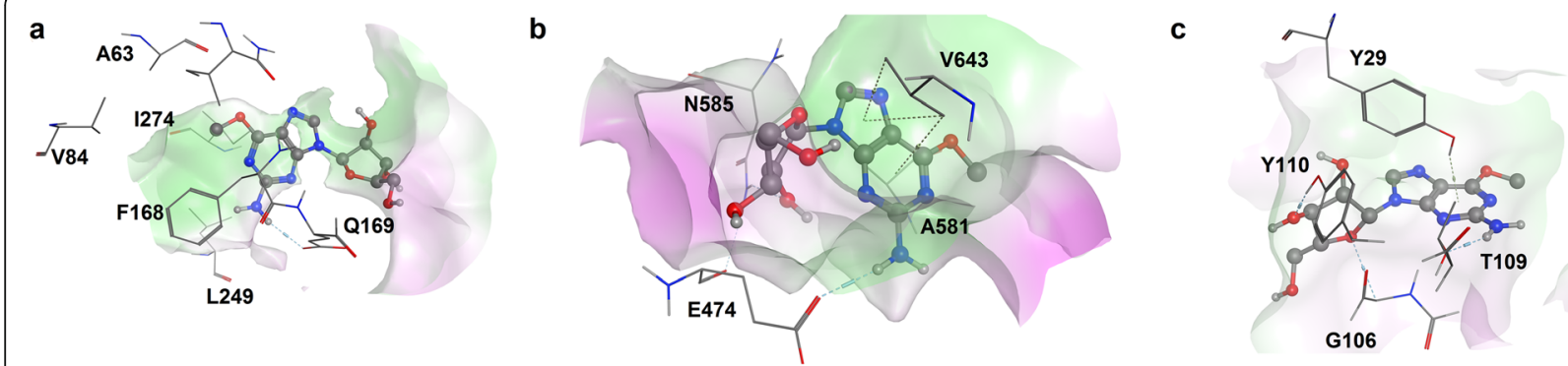

Fig. 2 Binding poses of nelarabine within the binding cavities of $\mathbf{a} A_{2} A R, \mathbf{b}$ PAD and $\mathbf{c}$ SIP receptor. In each of them carbon atoms are colored grey while ligand molecules are presented in ball and stick format. Hydrogen, arene- $\mathrm{H}$ and arene-carbon bonds are shown in cyan and light yellow respectively. Only interacting amino acid residues are shown for clarity 
binding affinity for all the 15 studied anti-psoriatic targets than their co-crystallized ligands. The similarity between the mechanisms of action of psoriasis and the diseases (cancer and viral) which the 12 drugs are currently indicated seems to confirm the in-silico prediction. A recent review on psoriasis and its treatment [47] suggests that none of these twelve drugs is currently prescribed for managing the psoriatic condition. Although some drugs used for managing psoriasis at the moment, like metronidazole, share a common structural motif with our virtual hits, we consider these twelve compounds as possible candidates that can be repositioned for managing psoriasis. In the future, we hope to validate the anti-psoriatic property of the 12 drugs in a biological assay.

\section{Abbreviations}

3-D: Three dimensional; P38-MAPK: Mitogen-activated Protein Kinase-p38; PAD: Peptidylarginine Deiminase; PDB: Protein data bank; PDE-

4: Phosphodiesterase-4; Pim-1 kinase: Provirallntegration site for Moloney Murine Leukemia Virus-1 Kinase; PKC: Protein Kinase C; RAC-1: Ras-related C3 Botulinum Toxin Substrate-1; S1PR: Sphingosine 1-Phosphate Receptor; SPK: Protein Kinase C; TNF-a: Tumor Necrosis Factor-alpha

\section{Acknowledgments}

FNK would acknowledge the Alexander von Humboldt Foundation (Germany) for a generous donation of scientific equipment and software licenses.

\section{Authors' contributions}

A.I. and E.O. did the formal analysis, project administration, provided resources and software, and wrote the original draft. E.N.D. provided resources and software and wrote the original draft. F.N.-K. Carried out the project administration, conceptualization, validation of the results and general supervision. The author(s) read and approved the final manuscript.

\section{Funding}

FNK would like to acknowledge the European Structural and Investment Funds, OP RDE-funded project 'ChemJets' (No. CZ.02.2.69/0.0/0.0/16_027/ 0008351). Al appreciates funding from African-German Network of Excellence in Sciences (AGNES) through Junior Researchers Grant (JRG).

\section{Availability of data and materials}

All data generated or analysed during this study are included in this published article.

\section{Declarations}

Ethics approval and consent to participate

Not applicable.

\section{Consent for publication}

Not applicable.

\section{Competing interests}

There are no conflicts of interest among the authors.

\section{Author details}

'Department of Pharmaceutical and Medicinal Chemistry, University of Nigeria, Nsukka, Nigeria. ${ }^{2}$ Department of Science Laboratory and Technology, University of Nigeria, Nsukka, Nigeria. ${ }^{3}$ Department of Chemistry, University of Buea, Buea, Cameroon. ${ }^{4}$ Department of Pharmaceutical Chemistry, Martin-Luther University Halle-Wittenberg, Halle (Saale), Germany.
Received: 6 May 2021 Accepted: 14 June 2021

Published online: 05 July 2021

\section{References}

1. World Health Organization (2016). Global report on psoriasis. (https://apps who.int/iris/handle/10665/204417). ISBN: 978924 1565189. Accessed 5 Nov 2019.

2. Lowes MA, Russell CB, Martin DA, Towne JE, Krueger JG. The IL-23/T17 pathogenic axis in psoriasis is amplified by keratinocyte responses. Trends Immunol. 2013;34(4):174-81. https://doi.org/10.1016/j.it.2012.11.005.

3. Parisi R, Symmons DP, Griffiths CE. Global epidemiology of psoriasis: a systematic review of incidence and prevalence. J Investigative Dermatol. 2013:133(2):377-85. https://doi.org/10.1038/jid.2012.339.

4. Sharma J, Balakrishnan L, Datta KK. A knowledgebase resource for interleukin-17 family mediated signaling. J Cell Comm Signaling. 1999;9: 291-6. https://doi.org/10.1007/s12079-015-0297-3.

5. Ghosh A, Panda S. Recent understanding of the etiopathogenesis of psoriasis. Indian J Pediatric Dermatol. 2017;18(19):1-8. https://doi.org/10.41 03/2319-7250.195569.

6. Villasenor-ParkJ WD, Grandinetti L. Psoriasis: evolving treatment for a complex disease. Clevel and Clinic J Med. 2012;79(19):413-23. https://doi. org/10.3949/ccjm.79a.11133.

7. Lonnberg AS, Zachariae C, Skov L. Targeting of interleukin-17 in the treatment of psoriasis. Clin Cosmetic Investig Dermatol. 2014;7:251-9. https://doi.org/10.2147/CCID.S67534.

8. Gaffen SL. Recent advances in the IL-17 cytokine family. Curr Opinion Immunol. 2011;23(19):613-9. https://doi.org/10.1016/j.coi.2011.07.006.

9. Mease PJ, Armstrong AW. Managing patients with psoriatic disease: the diagnosis and pharmacologic treatment of psoriatic arthritis in patients with psoriasis. Drugs. 2014;74(4):423-41. https://doi.org/10.1007/s40265-014-0191-y.

10. Torres T, Filipe P. Small molecules in the treatment of psoriasis. Drug Dev Res. 2015;76(19):215-27. https://doi.org/10.1002/ddr.21263.

11. Ashburn $\Pi$, Thor KB. Drug repositioning: identifying and developing new uses for existing drugs. Nat Rev Drug Discov. 2004;3(19):673-83. https://doi. org/10.1038/nrd1468.

12. Hurle MR, Yang L, Xie Q, Rajpal DK, Sanseau P, Agarwal P. Computational drug repositioning: from data to therapeutics. Clin Pharmacol Therapeut. 2013;93(19):335-41. https://doi.org/10.1038/clpt.2013.1.

13. Govindaraj RG, Naderi M, Singha M, Lemoine J, Brylinski M. Large-scale computational drug repositioning to find treatments for rare diseases. Syst Biol Appl. 2018;4(19):1-10. https://doi.org/10.1038/s41540-018-0050-7.

14. Rodriguez-Esteban RA. Drug-centric view of drug development: how drugs spread from disease to disease. PLoS Comput Biol. 2016;12(4):e1004852. https://doi.org/10.1371/journal.pcbi.1004852.

15. Li YY, Jones JMS. Drug repositioning for personalized medicine. Genome Med. 2012;4(3):27. https://doi.org/10.1186/gm326.

16. Hernandez JJ, Pryszlak M, Smith L, Yanchus C, Kurji N, et al. Giving drugs a second chance: overcoming regulatory and financial hurdles in repurposing approved drugs as Cancer therapeutics. Front Oncol. 2017;7(19):273-3607. https://doi.org/10.3389/fonc.2017.00273.

17. Sleire L, Førde HE, Netland IA, Leiss L, Skeie BS, Enger PØ. Drug repurposing in cancer. Pharmacol Res. 2017;124(19):74-91. https://doi.org/10.1016/j.phrs.2 017.07.013.

18. Ntie-Kang F, Nwodo NJ, Ibezim A, Simoben CV, Karaman B, Ngwa VF, et al. Molecular modeling of potential anticancer agents from African medicinal plants. J Chem Inf Model. 2014;54:2433-50. https://doi.org/10.1021/ci5003697.

19. Ibezim A, Nwodo NJ, Nnaji NJN, Ujam OT, Olubiyi OO, Mbah CJ. In silico investigation of morpholines as novel class of trypanosomal triosephosphate isomerase inhibitors. Med Chem Res. 2016;26(1):180-9. https://doi.org/10.1007/s00044-016-1739-z.

20. Ibezim A, Obi BC, Oforkansi MN, Mbah CJ, Nwodo NJ. Discovery of trypanocidal bioactive leads by docking study, molecular dynamic simulation and in vivo screening. ChemistrySelect. 2018;3:2386-9. https://doi.org/10.1002/slct.201702972.

21. Ibezim A, Olubiyi OO, Ata K, Mbah CJ, Nwodo NJ. Structure-based study of natural poducts with anti-Schistosoma activity. Curr Comput Aided Drug Des. 2017;13(2):91-100. https://doi.org/10.2174/1573409913666170119114859.

22. Ibezim A, Onoabedje EA, Adaka IC, Omeje KO, Onoabedje US, Obi BC. Carboxamides bearing sulfonamide functionality as potential novel phospholipase A2 inhibitors. ChemistrySelect. 2020:5:14416-21. https://doi. org/10.1002/slct.202003784. 
23. Ibezim A, Onyia K, Ntie-Kang F, Nwodo NJ. Drug-like properties of potential anti-cancer compounds from Cameroonian flora: a virtual study. J Applied Pharm Sci. 2015;5:133-7. https://doi.org/10.7324/JAPS.2015.50622.

24. Asogwa FC, Ibezim A, Ntie-Kang F, Asogwa CJ, Okoye COB. Anti-psoriatic and immunomodulatory evaluation of Psorospermum febrifugum Spach and its phytochemicals. Sci Afr. 2020;7(19):e00229. https://doi.org/10.1016/j.sciaf.2 019.e00229.

25. Irwin JJ, Tang KG, Young J, Dandarchuluun C, Wong BR, Khurelbaatar M, et al. ZINC20-a free Ultralarge-scale chemical database for ligand discovery. J Chem Inf Model. 2020;60(12):6065-73. https://doi.org/10.1021/acs.jcim. 0c00675.

26. Molecular Operating Environment (MOE), 2014.01; Chemical Computing Group ULC, 1010 Sherbooke St. West, Suite \#910, Montreal, QC, Canada, H3A 2R7, 2014.

27. Halgren TA. Merck molecular forcefield. J Comput Chem. 1996;17(5-6):490641. https://doi.org/10.1002/(SICI)1096-987X(199604)17:5/6<490::AID-JCC1>3. 0.CO;2-P.

28. Berman HM, Westbrook J, Feng Z, Gilliland G, Bhat TN, Weissig H, et al. The protein data bank. Nucleic Acids Res. 2000;28(19):235-342. https://doi.org/1 0.1093/nar/28.1.235.

29. Scott WRP, Hunenberger PH, Tironi IG, Mark AE, Billeter SR, Fennen J, et al. The GROMOS biomolecular simulation program package. J Phys Chem. 1999;103(19):3596-607. https://doi.org/10.1021/jp984217f.

30. Aslam A, Griffiths CEM. Drug therapies in dermatology. Clinic Med. 2014; 14(19):47-53. https://doi.org/10.7861/clinmedicine.14-1-47.

31. Winge MCG, Ohyama B, Dey CN, Boxer LM, Li W, et al. () RAC1 activation drives pathologic interactions between the epidermis and immune cells. J Clin Invest. 2016;126(19):2661-77. https://doi.org/10.11 72/JCl85738.

32. Ronholt K, Iversen L. Old and new biological therapies for psoriasis. Int J Mol Sci. 2017;18(19):2297-3607. https://doi.org/10.3390/ijms18112297.

33. Thorarensen A, Dowty ME, Banker ME, et al. Design of a Janus Kinase 3 (JAK3) specific inhibitor 1-((2S,5R)-5-((7H-Pyrrolo [2,3-d]pyrimidin-4-yl)amino)2-methylpiperidin-1-yl)prop-2-en-1-one (PF06651600) allowing for the interrogation of JAK3 signaling in humans. J Med Chem. 2017;60(19):197193. https://doi.org/10.1021/acs.jmedchem.6b01694.

34. Ibezim A, Ezechukwu EA. In-silico study of flavonoids from Cassia tora as potential anti-psoriatic agent. J Appl Pharmaceut Sci. 2019;9(4):082-7. https://doi.org/10.7324/JAPS.2019.90410.

35. Bhatia KH, Singh H, Grewal N, Natt KN. O Sofosbuvir: A novel treatment option for chronic hepatitis C infection. J Pharmacol Pharmacotherap. 1999; 5:278-84. https://doi.org/10.4103/0976-500X.142464.

36. Daniel JD, Daohai Y, Jeffrey $\amalg$, Steven EC, Richard MS, Alison TS, et al. Nelarabine induces complete remissions in adults with relapsed or refractory T-linkage acute lymphoblastic leukaemia or lymphoblastic lymphoma: Cancer and leukemia group B study 19801. Blood. 2007;109(19): 5136-42. https://doi.org/10.1182/blood-2006-11-056754.

37. Ceen-Ming T, Tung OU, Yun Y. Management of chronic hepatitis B infection: Current treatment guidelines, challenges, and new developments. World J Gastroenterol. 1999;20:6262-78. https://doi.org/10.3748/wjg.v20.i20.6262.

38. Pession A, Masetti $R$, Kleinschmidt K, Martoni A. Use of clofarabine in acute childhood leukaemia. Biol: Targets Therapy. 2010;4:111-8. https://doi.org/1 0.2147/BTT.S10123.

39. Tan BH. Cytomegalovirus treatment. Curr Treatment Options in Inf Dis. 2014; 6:256-70. https://doi.org/10.1007/s40506-014-0021-5.

40. Focacetti C, Bruno A, Magnani E, Bartolino D, Principi E, et al. Effects of 5flourouracil on morphology, cell cycle proliferation, apoptosis, autophagy and ROS production in endothelial cells and cardiomyocytes. PLoS One. 2015;10(19):e0115686. https://doi.org/10.1371/journal.pone.0115686.

41. Sauerbrei A. Optimal management of genital herpes: current perspectives. Inf Drug Resist. 2016;9(19):129-41. https://doi.org/10.2147/IDR.S96164.

42. Zhang L, Hao CQ, Liu JF, Wang M. Meta-analysis of the short-term effects of lamivudine treatment for severe chronic hepatitis B. Virology J. 2013;10(19): 1-12. https://doi.org/10.1186/1743-422X-10-134.

43. Grever MR, Abdel-Wahab O, Andritsos LA, Banerji V, Barrientos J, et al. Consensus guidelines for the diagnosis and management of patient of with classic hairy cell leukemia. Blood. 2017;129(19):553-60. https://doi.org/10.11 82/blood-2016-01-689422.

44. Pau AK, George JM. Antiretroviral therapy: current drugs. Infect Dis Clin N Am. 2014;28(3):371-402. https://doi.org/10.1016/j.idc.2014.06.001.
45. Hus I, Rolinski J. Current concepts in diagnosis and treatment of chronic lymphocytic leukaemia. Contemp Oncol (Pozn). 2015;19(19):361-7. https:// doi.org/10.5114/wo.2015.55410

46. Li W, Gong X, Sun M, Zhao X, Gong B, Wei H, et al. High-dose cytarabine in acute myeloid leukemia treatment: a systematic review and meta-analysis. PLoS One. 2014;9(10):e110153. https://doi.org/10.1371/journal.pone.0110153.

47. Sowmya C, Lavakumar V, Venkateshan N, Anitha P, Senthilnathan B. Current trends in treatment and management of psoriasis: an updated review. Int Res J Pharm. 2018;9(3):6-16. https://doi.org/10.7897/2230-8407.09336.

\section{Publisher's Note}

Springer Nature remains neutral with regard to jurisdictional claims in published maps and institutional affiliations.
Ready to submit your research? Choose BMC and benefit from:

- fast, convenient online submission

- thorough peer review by experienced researchers in your field

- rapid publication on acceptance

- support for research data, including large and complex data types

- gold Open Access which fosters wider collaboration and increased citations

- maximum visibility for your research: over $100 \mathrm{M}$ website views per year

At $\mathrm{BMC}$, research is always in progress.

Learn more biomedcentral.com/submissions 